\title{
Correction to: Spatial and temporal distribution of carbon dioxide gas using GOSAT data over IRAN
}

\author{
Samereh Falahatkar • Seyed Mohsen Mousavi • \\ Manochehr Farajzadeh
}

Published online: 26 January 2018

(C) Springer International Publishing AG, part of Springer Nature 2018

\section{Correction to: Environ Monit Assess (December 189, Issue 12:627 \\ https://doi.org/10.1007/s10661-017- 6285-8}

The original version of this article unfortunately contained an error in the affiliation section.

The affiliation of the third author should have been Tarbiat Modares University instead of University of Tarbiat Modares University.

The corrected affiliation is shown below.

The online version of the original article can be found at https://doi.org/10.1007/s10661-017-6285-8.

S. Falahatkar $(\bowtie) \cdot$ S. M. Mousavi

Environmental Science Department, Faculty of Natural Resources and Marine Science, Tarbiat Modares University, Noor,

Mazandaran, Iran

e-mail: samereh.falahatkar@modares.ac.ir

M. Farajzadeh

Department of Geography, Tarbiat Modares University, Tehran, Iran 